\title{
Factors Associated with Gastrointestinal Parasitic Infections among Young Population in Northeast Brazil
}

\author{
Juliana Vasconcelos Lyra da Silva, ${ }^{1,2}$ Gilberto Fontes, ${ }^{1,3}$ Célia Dias dos Santos, ${ }^{2}$ \\ Rafael Vital dos Santos, ${ }^{1}$ and Eliana Maria Mauricio da Rocha ${ }^{1,3}$ \\ ${ }^{1}$ Instituto de Ciências Biológicas e da Saúde da Universidade Federal de Alagoas, 57072-970 Maceió, AL, Brazil \\ ${ }^{2}$ Faculdade de Nutrição da Universidade Federal de Alagoas, 57072-970 Maceió, AL, Brazil \\ ${ }^{3}$ Universidade Federal de São João del Rei, Campus Centro Oeste, 35501-296 Divinópolis, MG, Brazil
}

Correspondence should be addressed to Eliana Maria Mauricio da Rocha; eliana.rocha@pq.cnpq.br

Received 27 February 2016; Revised 11 June 2016; Accepted 30 June 2016

Academic Editor: Paul-Louis Woerther

Copyright (c) 2016 Juliana Vasconcelos Lyra da Silva et al. This is an open access article distributed under the Creative Commons Attribution License, which permits unrestricted use, distribution, and reproduction in any medium, provided the original work is properly cited.

\begin{abstract}
Background. Intestinal parasitic infections constitute a major public health problem that is frequently associated with poverty, inadequate sanitation, and the nutritional status of the population. Objective. The aim of the present study is to investigate the possible association of parasitic infections, sanitary conditions, hygiene practices, and the nutritional and socioeconomic status of a poor youth population. Methods. A cross-sectional study was conducted with 367 children and adolescents inhabiting a substandard settlement in the urban area of Maceió (Alagoas State, Brazil). Data collection included socioeconomic status, anthropometric measurements, fecal sample examinations, and laboratory blood analysis. The identification of factors associated with gastrointestinal parasitic infections was undertaken through bi- and multivariate analyses. Results. Stool sample analysis obtained from 300 individuals revealed that 204 (68\%) were infected with at least one parasite species and of these 130 (63.7\%) were polyparasitized. No significant associations were identified between low height for age (stunted), parasitic infections, and polyparasitism. There was also no association between family income and parasitosis. However, low socioeconomic status proved to be a potential risk factor for parasitic infections. Conclusion. Actions must be taken to improve sanitation, housing, and environmental conditions in order to eliminate the risk factors for parasitic infections, and thereby guarantee a better quality of life for this population.
\end{abstract}

\section{Introduction}

Parasitic intestinal infections are more prevalent in schoolaged children and cause a wide range of complications, including bowel obstruction, anorexia, anemia, diarrhea, and malabsorption [1]. Parasitic infections, undernutrition, and iron deficiency anemia (IDA) are common problems in developing countries and they are mainly due to poverty which contributes to food insecurity, unclean surroundings, and limited access to health care [2]. These diseases result in growth retardation and the impairment of neuropsychomotor development, immune function, productive ability, and intellectual capacity $[1,3]$.
Undernutrition and IDA are commonly associated with intestinal parasitosis, although some studies have raised doubts regarding such associations. Tsuyuoka et al. [4] confirmed the association of intestinal parasitic infections with malnutrition but not with anemia. However, Monteiro [5] considered intestinal helminthiasis and inadequate food intake to be prime factors in the pathophysiology of anemia and malnutrition. Muniz-Junqueira and Queiróz [6] found an association between only malnutrition and giardiasis, whereas Castro et al. [7] reported a correlation of anemia with Entamoeba histolytica infection. To date, the relationship of intestinal parasitic infections with some nutritional indicators remains not entirely clear. Therefore, the aim of this 


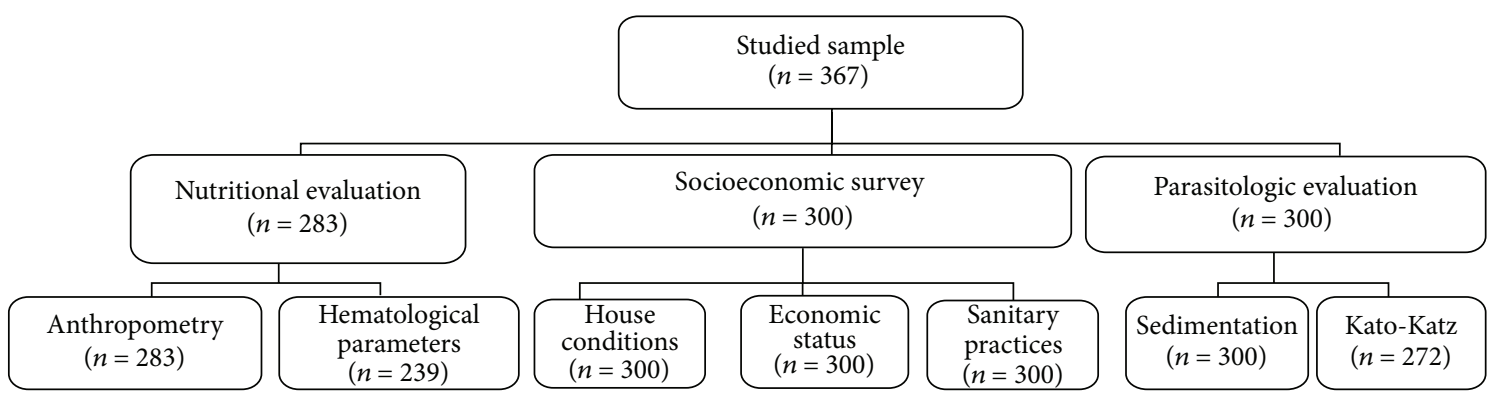

FIGURE 1: Flow chart of the number of participants included in each evaluation of the study.

study is to investigate the associations that may exist between enteroparasitosis and nutritional and socioeconomic variables.

\section{Materials and Methods}

2.1. Study Design. A cross-sectional study was undertaken enrolling 367 children and adolescents, including 186 boys (50.7\%) and 181 girls $(49.3 \%)$ aged 0 to 15 years (mean 7.7 \pm 4.2 years). The sample size was calculated based on an expected prevalence of 53\%, an acceptable error of $10 \%$, and a $99 \%$ confidence interval. This prevalence was obtained from a preliminary study conducted in the area [8]. This calculation returned a minimal sample size of 273 children, which was increased to compensate for anticipated losses during followup. A flow chart indicating the number of participants for each evaluation is presented in Figure 1.

2.2. Study Area. The subjects lived in the Reginaldo Valley, a substandard settlement in the urban area of Maceió (Alagoas State, Brazil), which covers approximately $60,000 \mathrm{~m}^{2}$ with an estimated population of 65,000 people. The region was endemic for lymphatic filariasis until 2005 [9]. Despite being an ideal setting for the transmission of enteroparasites, the epidemiological situation of this area has not been described. The households in this study were randomly selected.

2.3. Socioeconomic Survey. A household survey was undertaken to collect the socioeconomic data. The variables were divided into three groups: living conditions, economic indicators, and behavior related to sanitary education. The socioeconomic level of the participants was classified according to the Brazilian Economic Classification Criterion ABEP-2008 [10]. Social categorization from class A to class E (from highest to lowest income class) is based mainly on minimum wage per month per family, the parental educational level, and possession of household items (TV, stove, refrigerator, etc.). Table 1 shows the characteristics of the studied population.

2.4. Parasitological Analysis. Fecal samples were processed and evaluated using techniques based on spontaneous sedimentation [11] and Katz et al. [12] techniques. To be regarded as infected, the patient had to present a positive diagnosis for an intestinal parasite in at least one of the tests performed.
TABle 1: Demographics and behavioral characteristics of children aged 0 to 15 years, living in a substandard settlement in Maceió, Alagoas, Brazil.

\begin{tabular}{lc}
\hline Variables & Number of participants (\%) \\
\hline Gender & $186(50.7)$ \\
Male & $181(49.3)$ \\
Female & $133(36.2)$ \\
\hline Age group & $135(36.8)$ \\
$0-5$ & $99(27.0)$ \\
$6-10$ & \\
$11-15$ & $157(52.3)$ \\
\hline Number of household members & $143(47.7)$ \\
$\leq 5$ & \\
$>5$ & $43(14.4)$ \\
\hline Toilet type in use & $174(58.0)$ \\
No toilet & $22(7.3)$ \\
Indoor toilet with flush & $37(12.3)$ \\
Indoor toilet without flush & $24(8.0)$ \\
Pit latrine with water & \\
Pit latrine & $2(0.7)$ \\
\hline Social status & $21(7.0)$ \\
C1 & $141(47.0)$ \\
C2 & $136(45.3)$ \\
D & \\
E & $44(14.7)$ \\
\hline Family income (MW ${ }^{* *} /$ family/month) & $97(32.3)$ \\
Unknown & $91(30.3)$ \\
$<1$ & $50(16.7)$ \\
1 & $16(5.3)$ \\
$1-2$ & $2(0.7)$ \\
$2-3$ & $123(41.0)$ \\
$3-5$ & $177(59.0)$ \\
\hline Footwear use & \\
Yes & $212(70.7)$ \\
No & MW: minimum wage. \\
\hline Contact with natural water sources & \\
Yes & \\
No & \\
${ }^{*}$ Economic classification proposed by ABEP $\left.[10] ; * 3\right)$ \\
$\quad{ }^{*}$
\end{tabular}

2.5. Anthropometric Evaluation. Anthropometric evaluations were performed by trained personnel, following the technical procedures of the Brazilian Ministry of Health [13]. Height for age $(\mathrm{H} / \mathrm{A})$ and body mass index for age (BMI/A) were calculated and expressed as $Z$ scores $[14,15]$. The data 
TABLE 2: Cut-off point criteria for nutritional status and hematological parameters according to age, for the evaluation of a sample of people aged 0 to 15 years in Maceió, Alagoas, Brazil.

\begin{tabular}{|c|c|c|c|c|c|c|}
\hline \multicolumn{5}{|c|}{ Anthropometric indices and hematological parameters } & & \multirow[t]{2}{*}{ Reference } \\
\hline \multicolumn{6}{|c|}{ Nutritional status (H/A) } & \\
\hline $\begin{array}{l}\text { Classification } \\
\text { Score }\end{array}$ & $\begin{array}{c}\text { Very low height for age } \\
\qquad Z<-3\end{array}$ & $\begin{array}{l}\text { Low height for age } \\
-3 \leq Z<-2\end{array}$ & $\begin{array}{l}\text { Adequate height for age } \\
\qquad Z \geq-1\end{array}$ & & & {$[14,15]$} \\
\hline \multicolumn{7}{|c|}{ Nutritional status (BMI/A) } \\
\hline Classification & Malnourished & Risk & Eutrophy & Overweight & Obese & \\
\hline Score & $Z<-2$ & $-2 \leq Z<-1$ & $-1 \leq Z \leq 1$ & $1<Z \leq 2$ & $Z>2$ & {$[14,15]$} \\
\hline & & Hemoglobir & & & & \\
\hline Age & $6-59$ months & $5-11$ years & $12-15$ years & $\geq 15$ years & & \\
\hline Cut-off $(\mathrm{g} / \mathrm{dL})$ & $<11.0$ & $<11.5$ & $<12.0$ & 13.0 & & [17] \\
\hline \multicolumn{7}{|c|}{ Ferritin } \\
\hline Age & $<5$ years & $\geq 6$ years & & & & \\
\hline Cut-off (ng/mL) & $\geq 12$ & $\geq 15$ & & & & [17] \\
\hline \multicolumn{7}{|c|}{ Serum iron } \\
\hline Age & Age independent & & & & & \\
\hline Cut-off $(\mu \mathrm{g} / \mathrm{mL})$ & $<50$ & & & & & [18] \\
\hline
\end{tabular}

was statistically analyzed using WHO AnthroPlus [16] and Microsoft Office Excel ${ }^{\circledR}$ software.

2.6. Analysis of Hemoglobin, Ferritin, and Iron. Iron status was determined by measuring the hemoglobin $(\mathrm{Hb})$, ferritin (SF), and iron (SI) levels in blood collected from each participant through venipuncture. The cyanmethemoglobin method, an automated chemiluminescence system (ACS $180^{\circledR}$, Bayer HealthCare), and spectrophotometry were used to determine, respectively, $\mathrm{Hb}, \mathrm{SF}$, and SI levels $[17,18]$, Table 2.

2.7. Statistical Analysis. Bivariate (chi-square) and multivariate (logistic regression) statistical analyses were performed to evaluate the association between variables. Odds ratios (OR) (95\% CIs) were calculated as a measurement of the strengths of associations. Relevant variables that achieved $p$ value $<$ 0.20 in the bivariate analyses were included in the stepwise logistic regression model. For the multivariate logistic regression final model only variables associated with the dependent variable (intestinal parasitic infection) were retained $(p<$ $0.05)$. Variables with more than two categories were redefined into dummy variables (categories 0-1). Statistical analysis was done using the Statistical Package for Social Sciences (SPSS), version 11.5, and STATA Statistical Software, version 10.

2.8. Ethical Considerations. The study was approved by the Research Ethics Committee of the Federal University of Alagoas (number 006491/2004-85). Only subjects whose parent/legal guardian signed a consent form participated in this study.

\section{Results and Discussion}

Overall, out of the 300 individuals examined for intestinal parasites, 204 (68\%) were infected with at least one species. High rates of prevalence have already been found in Brazil in areas with precarious socioeconomic and hygienic conditions. In studies conducted by Gomes et al. [19] in the state of Rio de Janeiro and by Buschini et al. [20] in the city of Guarapuava, Paraná State, parasitic infections were diagnosed in $63.2 \%$ of homeless people and in $75.3 \%$ of school-aged children, respectively. Fontes et al. [21] found that $92 \%$ of school-aged children, ranging from 5 to 18 years old, living in the city of Barra de Santo Antônio in the state of Alagoas, were infected with at least one species of intestinal parasite.

Eleven species of parasites were detected in this study, and $130(63.7 \%)$ of the infected individuals suffered from polyparasitism. The number of parasite species harbored per host ranged from one to six, with a mean of $2.1( \pm 1.1)$ and median of two parasite species per host. Helminthic infections were more common than protozoal infections, mainly Trichuris trichiura (51.5\%) and Ascaris lumbricoides (46.6\%) (Figure 2). Ascariasis was also the most frequently recorded parasitic infection in school-aged children from Alagoas [3, 19]. Similar results were found by Lander [22] in a study conducted in the northeast region of Brazil. In several Latin American communities, infection with $A$. lumbricoides often affects more than 20\% [23] of the population.

In bivariate analysis, the variables that had significant positive associations (95\% CI) with intestinal parasite infections were socioeconomic status, footwear use, and number of household members (Table 3).

In the complete multivariate model, in addition to the aforementioned variables, indoor toilet, family income, and contact with natural water sources were also included as variables. The multivariate analysis is shown in Table 4. Only socioeconomic status (class E) and households with more than five individuals maintained significant associations with 95\% CIs.

Nematian et al. [24] studied school-aged children in Tehran (Iran) and demonstrated a relationship between number of siblings and parasitic infection. It is likely that having a large number of people in a household results in less attention to positive health habits. In addition, larger families usually have a lower socioeconomic status. 
TABLE 3: Bivariate analysis for factors potentially associated with intestinal parasitic infection among children aged 0 to 15 years, from a substandard settlement in Maceió, Alagoas, Brazil.

\begin{tabular}{|c|c|c|c|c|c|c|}
\hline \multirow{2}{*}{ Variables } & \multirow{2}{*}{ Number of individuals } & \multicolumn{2}{|c|}{ Infected } & \multirow{2}{*}{ Odds ratio } & \multirow{2}{*}{$95 \%$ CI } & \multirow{2}{*}{$p$ value } \\
\hline & & $n$ & $\%$ & & & \\
\hline \multicolumn{7}{|l|}{ Age group } \\
\hline $0-5$ & 63 & 42 & 66.7 & 1 & & \\
\hline $6-10$ & 77 & 49 & 63.6 & 0.9 & $0.4-1.8$ & 0.71 \\
\hline $11-15$ & 41 & 30 & 73.2 & 1.4 & $0.6-3.3$ & 0.48 \\
\hline \multicolumn{7}{|l|}{ Gender* } \\
\hline Male & 92 & 59 & 64.1 & & & \\
\hline Female & 89 & 62 & 69.7 & 1.3 & $0.7-2.4$ & 0.43 \\
\hline \multicolumn{7}{|l|}{ Social status ${ }^{* * *}$} \\
\hline $\mathrm{C}$ and $\mathrm{D}$ & 105 & 63 & 60.0 & & & \\
\hline $\mathrm{E}$ & 76 & 58 & 76.3 & 2.1 & $1.1-4.1$ & $0.02^{* *}$ \\
\hline \multicolumn{7}{|l|}{ Family income $e^{* * * *}$} \\
\hline$>1$ minimum wage & 46 & 27 & 58.7 & & & \\
\hline$\leq 1$ minimum wage & 103 & 71 & 68.9 & 1.6 & $0.8-3.2$ & 0.22 \\
\hline \multicolumn{7}{|c|}{ Number of household members ${ }^{* * *}$} \\
\hline$\leq 5$ & 100 & 59 & 59.0 & & & \\
\hline$>5$ & 81 & 62 & 76.5 & 2.3 & $1.2-4.3$ & $0.01^{* *}$ \\
\hline \multicolumn{7}{|l|}{ Indoor toilet } \\
\hline Yes & 120 & 78 & 65.0 & & & \\
\hline No & 61 & 43 & 70.5 & 1.3 & $0.7-2.5$ & 0.46 \\
\hline \multicolumn{7}{|l|}{ Footwear use $\mathrm{F}^{* * *}$} \\
\hline Yes & 78 & 47 & 60.3 & & & \\
\hline No & 103 & 74 & 71.8 & 1.7 & $0.9-3.14$ & $0.10^{* *}$ \\
\hline \multicolumn{7}{|c|}{ Contact with natural water sources } \\
\hline No & 135 & 88 & 65.2 & & & \\
\hline Yes & 46 & 33 & 71.7 & 1.4 & $0.7-2.8$ & 0.41 \\
\hline \multicolumn{7}{|l|}{ Anemia } \\
\hline No & 161 & 109 & 67.7 & & & \\
\hline Yes & 20 & 12 & 60.0 & 0.7 & $0.3-1.9$ & 0.49 \\
\hline \multicolumn{7}{|l|}{ Low level of ferritin } \\
\hline No & 152 & 100 & 65.8 & & & \\
\hline Yes & 29 & 21 & 72.4 & 1.4 & $0.6-3.3$ & 0.49 \\
\hline \multicolumn{7}{|l|}{ Low level of iron } \\
\hline No & 117 & 78 & 66.7 & & & \\
\hline Yes & 64 & 43 & 67.2 & 1.0 & $0.5-2.0$ & 0.94 \\
\hline \multicolumn{7}{|l|}{ Growth stunting } \\
\hline No & 160 & 107 & 66.9 & & & \\
\hline Yes & 21 & 14 & 66.7 & 1.0 & $0.4-2.6$ & 0.98 \\
\hline \multicolumn{7}{|l|}{ Low weight } \\
\hline No & 173 & 114 & 65.9 & & & \\
\hline Yes & 8 & 7 & 87.5 & 3.6 & $0.4-30.1$ & 0.23 \\
\hline
\end{tabular}

${ }^{*}$ Control variables selected for multivariate logistic regression model.

${ }^{* *}$ Statistically significant difference.

${ }^{* * *}$ Selected variables for multivariate logistic regression $(p<0.20)$.

**** 32 participants without income information.

Results from different investigations have been in disagreement with regard to both stunting and undernutrition and the relationship these have with parasitic infection. No such relationship was found to exist in the present study.
Similar results were obtained in the investigation conducted by Casapía et al. [25]; these authors studied preschool-aged children and found no evidence of a relationship between underweight and parasitic infections or polyparasitism. In 
TABLE 4: Final model multivariate logistic regression analysis for factors potentially associated with intestinal parasite infection, among children aged 0 to 15 years, from a substandard settlement in Maceió, Alagoas, Brazil.

\begin{tabular}{|c|c|c|c|}
\hline Risk v & Adjusted odds ratio & $95 \% \mathrm{CI}$ & $p$ value \\
\hline Socia & 2.4 & $1.2-4.6$ & $0.01^{*}$ \\
\hline$>5$ household members ${ }^{* * *}$ & 2.5 & $1.3-4.8$ & $0.01^{*}$ \\
\hline
\end{tabular}

${ }^{*}$ Statistical significance.

${ }^{* *}$ Reference categories: C and D.

${ }^{* * *}$ Reference category: $\leq 5$ household members.

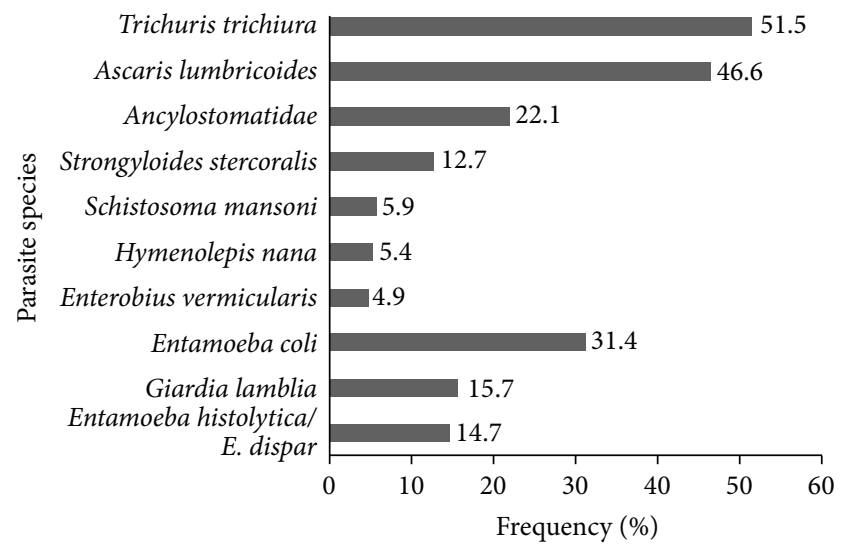

FIGURE 2: Frequency of parasite species identified in stool samples from children aged 0 to 15 years, living in a substandard settlement in Maceió, Alagoas.

contrast, Alvarado and Vásquez [26] reported a higher prevalence of acute malnutrition in children with polyparasitism and trichuriasis, while Phathammavong et al. [27] described a greater prevalence of underweight and nutritional stunting among school-aged children infected with intestinal parasites.

According to Santos [3], the lack of a correlation between nutritional deficits and parasitic infections could be explained mainly by the decline in the occurrence of malnutrition over the last few decades in Brazil as well as by the decrease of inadequate diets, by low levels of infection, and by the indiscriminate use of antiparasitic drugs obtained without a medical prescription.

A survey conducted in the semiarid region of Alagoas State revealed that $87.3 \%$ of the families were classified in the lowest economic stratum [28]. Furthermore, the state had the worst child development index score in Brazil $(\mathrm{CDI}=0.473)$ [29]. Therefore, establishing a plan of action targeted mainly against soil-transmitted parasites requires urgent attention. Social scientists in Brazil have repeatedly addressed the need to prioritize investment in sanitation and make sanitation one of the most important public policy initiatives [30]. The lives of these children are hampered by the same widespread poverty documented in other studies. Access to basic health services, education, and adequate housing will not become a reality unless specific actions are taken to improve the quality of life among people living in unsanitary conditions.

\section{Competing Interests}

The authors declare that they have no competing interests.

\section{Acknowledgments}

The authors would like to acknowledge Anny Karinny Calheiros Dutra Timóteo and Paula de Oliveira Queiroz Aciole for their technical assistance; Dr. Roberta Carvalho de Figueiredo for providing statistical support; and Flávia M. da Rocha Fontes and John Ashley for English review of the paper. Special thanks are due to the children who participated in this study. Funding for the study came from Pan American Health Organization (PAHO)/World Health Organization (WHO) (PFG 03/00001-3- BRA/CNT/0400506.001).

\section{References}

[1] L. S. Stephenson, M. C. Latham, and E. A. Ottesen, "Malnutrition and parasitic helminth infections," Parasitology, vol. 121, pp. S23-S38, 2000.

[2] WHO (World Health Organization), The World Health Reports 2002: Reducing Risks, Promoting Health Life, WHO, Geneva, Switzerland, 2002.

[3] C. D. Santos, Anemia, retardo do crescimento e enteroparasitoses em escolares da rede pública de Maceió, Alagoas [Dissertation], Instituto Materno Infantil de Pernambuco, IMIP, Recife, Brazil, 2001.

[4] R. Tsuyuoka, J. W. Bailey, A. M. Nery Guimarães, R. Q. Gurgel, and L. E. Cuevas, "Anemia and intestinal parasitic infections in primary school students in Aracaju, Sergipe, Brazil," Cadernos de Saude Publica, vol. 15, no. 2, pp. 413-421, 1999.

[5] C. A. Monteiro, "O problema da desnutrição no Estado de São Paulo (Brasil): informações disponíveis, lacunas no conhecimento e linhas de pesquisa prioritárias," Revista de Saúde Pública, vol. 19, no. 2, pp. 183-189, 1985.

[6] M. I. Muniz-Junqueira and F. O. Queiróz, "Relationship between protein-energy malnutrition, vitamin $\mathrm{A}$, and parasitoses in living in Brasília," Revista da Sociedade Brasileira de Medicina Tropical, vol. 35, no. 2, pp. 133-141, 2002.

[7] T. G. Castro, F. M. Campos, S. E. Priore et al., "Saúde e nutrição de crianças de 0 a 60 meses de um assentamento de reforma agrária, Vale do Rio Doce, MG, Brasil," Revista de Nutrição, vol. 17, no. 2, pp. 167-176, 2004.

[8] P. O. Queiroz, Avaliação e perspectiva de controle das geohelmintoses, esquistossomose mansônica e filariose linfática em áreas urbanas definidas de Maceió-Alagoas [M.S. dissertation], Universidade Federal de Alagoas, Maceió, Brazil, 2009, http://www .dominiopublico.gov.br/download/texto/cp107392.pdf.

[9] G. Fontes, A. B. Leite, A. R. V. De Lima, H. Freitas, J. P. Ehrenberg, and E. M. M. Da Rocha, "Lymphatic filariasis in Brazil: epidemiological situation and outlook for elimination," Parasites and Vectors, vol. 5, article 272, 2012.

[10] Associação Brasileiras de Empresas de Pesquisa (ABEP), Critério Padrão de Classificação Econômica Brasil/2008, Associação Brasileiras de Empresas de Pesquisa (ABEP), São Paulo, Brazil, 2007.

[11] A. O. Lutz, "Schistosomum mansoni e a Shistomatose segundo observações feitas no Brasil," Memórias do Instituto Oswaldo Cruz, vol. 11, pp. 121-144, 1919. 
[12] N. Katz, A. Chaves, and J. Pellegrino, "A simple device for quantitative stool thick-smear technique in Schistosomiasis mansoni.," Revista do Instituto de Medicina Tropical de Sao Paulo, vol. 14, no. 6, pp. 397-400, 1972.

[13] A. A. Fagundes, D. C. Barros, H. A. Duar, L. M. V. Sardinha, M. M. Pereira, and M. M. Leão, "Vigilância alimentar e nutricional-SISVAN: orientações básicas para a coleta, processamento, análise de dados e informação em serviços de saúde," Ministério da Saúde, Brasília, Brazil, 2004.

[14] MS-Ministério da Saúde, Protocolos do Sistema de Vigilância Alimentar e Nutricional. SISVAN na Assistência à Saúde, Ministério da Saúde, Secretaria de Atenção à Saúde. Departamento de Atenção Básica, Brasília, Brasil, 2008, http://189.28.128.100/ nutricao/docs/geral/protocolo_sisvan.pdf.

[15] World Health Organization, "WHO computation of centiles and z-scores for height-for-age, weight-for-age and BMI-forage," in Multicentre Growth Reference Study Group. WHO Child Growth Standards: Length/Height-for-Age, Weight-for-Age, Weight-for-Length, Weight-for-Height and Body Mass Index-forAge: Methods and Development, World Health Organization, Geneva, Switzerland, 2006.

[16] WHO, Anthroplus for Personal Computers Manual: Software for Assessing Growth of the World's Children and Adolescents, WHO, Geneva, Switzerland, 2009, http://www.who.int/growthref/ tools/en/.

[17] World Health Organization (WHO), Iron Deficiency Anaemia: Assessment, Prevention and Control-A Guide for Programme Managers, World Health Organization (WHO), Geneva, Switzerland, 2001.

[18] G. R. Lee, "Fatores nutricionais na produção e função dos eritrócitos," in Wintrobe: Hematologia Clínica, G. H. Lee, T. C. Bithell, J. Foerster, J. W. Athens, and J. N. Lukens, Eds., pp. 166207, Editora Manole, São Paulo, Brazil, 1998.

[19] T. C. Gomes, M. F. Almeida, L. A. Miura et al., "Helmintoses intestinais em população de rua da cidade do Rio de Janeiro," Revista da Sociedade Brasileira de Medicina Tropical, vol. 35, no. 5, pp. 531-532, 2002.

[20] M. L. Buschini, E. Pitnner, T. Czervinski et al., "Spatial distribution of enteroparasites among school children from Guarapuava, State of Paraná, Brazil," Revista Brasileira de Epidemiologia, vol. 10, no. 4, pp. 568-578, 2007.

[21] G. Fontes, K. K. Oliveira, A. K. Oliveira, and E. M. Rocha, "Influência do tratamento específico na prevalência de enteroparasitoses e esquistossomose mansônica em escolares do município de Barra de Santo Antônio, AL," Revista da Sociedade Brasileira de Medicina Tropical, vol. 36, no. 5, pp. 625-628, 2003.

[22] R. L. Lander, The nutritional status of disadvantaged preschool children attending daycares in Salvador, Northeast Brazil: a cross-sectional study [Ph.D. dissertation], University of Otago, Dunedin, New Zealand, 2012, http://hdl.handle.net/10523/2605.

[23] PAHO, Prevalence and Intensity of Infection of Soil-Transmitted Helminths in Latin America and the Caribbean Countries: Mapping at Second Administrative Level 2000-2010, PAHO, Washington, DC, USA, 2011.

[24] J. Nematian, E. Nematian, A. Gholamrezanezhad, and A. A. Asgari, "Prevalence of intestinal parasitic infections and their relation with socio-economic factors and hygienic habits in Tehran primary school students," Acta Tropica, vol. 92, no. 3, pp. 179-186, 2004.

[25] M. Casapía, S. A. Joseph, C. Núñez, R. Elham, and T. W. Gyorkos, "Parasite and maternal risk factors for malnutrition in preschool-age children in Belen, Peru using the new WHO child growth standards," British Journal of Nutrition, vol. 98, no. 6, pp. 1259-1266, 2007.

[26] B. E. Alvarado and L. R. Vásquez, "Determinantes sociales, prácticas de alimentación y consecuencias nutricionales del parasitismo intestinal en niños de 7 a 18 meses de edad en Guapi, Cauca," Biomédica, vol. 26, no. 1, pp. 82-94, 2006.

[27] O. Phathammavong, A. Moazzam, D. Xaysomphoo, A. Phengsavanh, and C. Kuroiwa, "Parasitic infestation and nutritional status among schoolchildren in Vientiane, Lao PDR," Journal of Paediatrics and Child Health, vol. 43, no. 10, pp. 689-694, 2007.

[28] A. M. A. Vasconcelos and H. S. Ferreira, "Prevalência de hipovitaminose A em crianças da região semi-árida de Alagoas (Brasil), 2007," Archivos Latinoamericanos de Nutrición, vol. 59, no. 2, pp. 152-158, 2009.

[29] UNICEF, "Situação da infância brasileira [crianças de 0 até 6 anos]: o direito à sobrevivência e ao desenvolvimento," UNICEF, Brasília, Brazil, 2005.

[30] A. L. L. Lima, A. C. F. Silva, S. C. Konno, W. L. Conde, M. H. D. Benício, and C. A. Monteiro, "Causas do declínio acelerado da desnutrição infantil no Nordeste do Brasil (1986-1996-2006)," Revista de Saúde Pública, vol. 44, no. 1, pp. 17-27, 2010. 


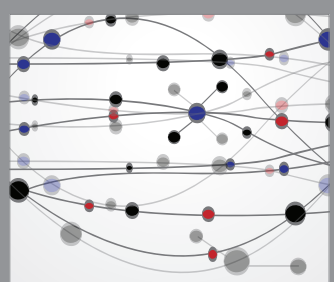

The Scientific World Journal
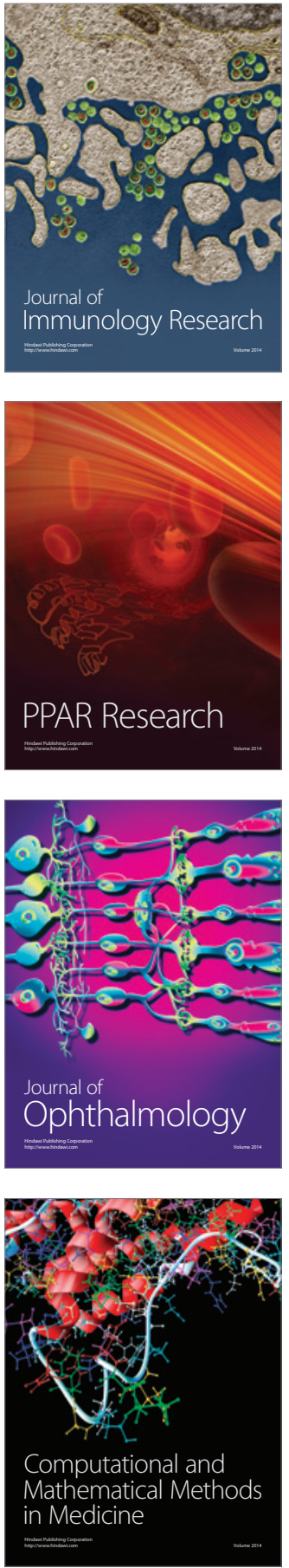

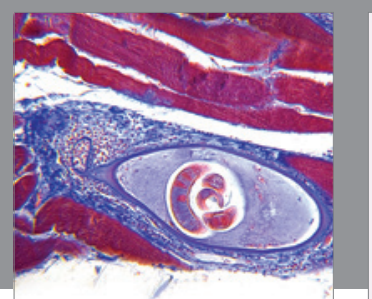

Gastroenterology Research and Practice

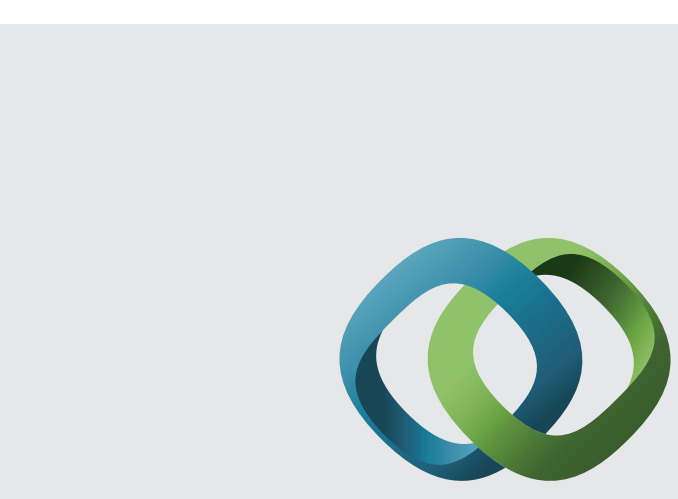

\section{Hindawi}

Submit your manuscripts at

http://www.hindawi.com
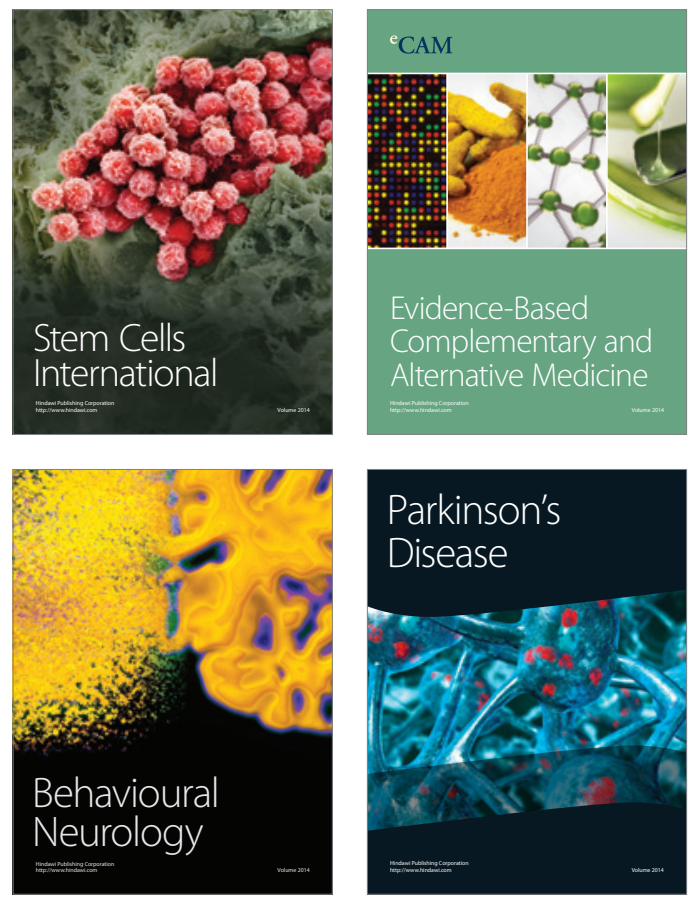
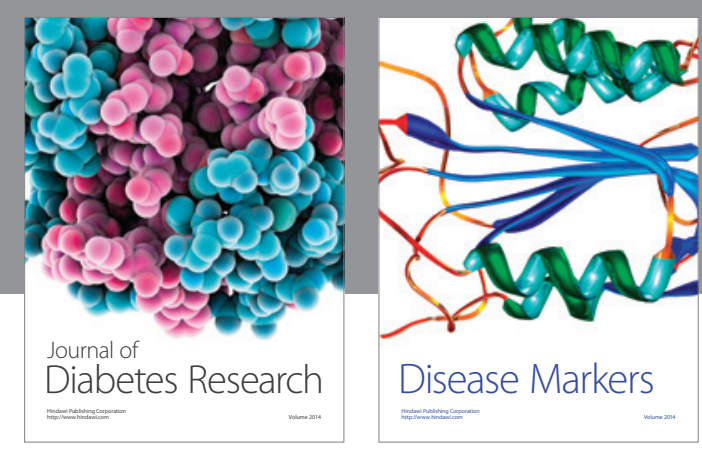

Disease Markers
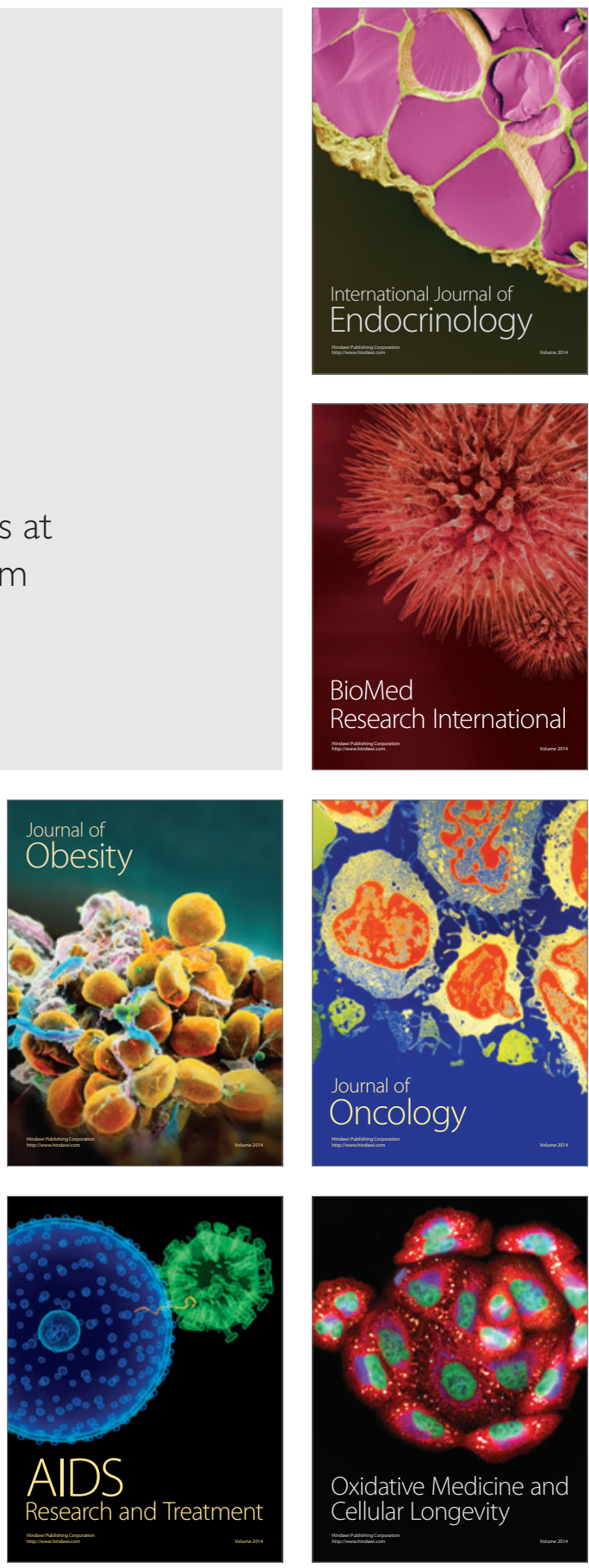